\title{
Calcium polystyrene sulfonate associated colonic mucosal injury-innocent bystander or pathogenic culprit?: a case report and literature review
}

\author{
Setthachai Piwchan ${ }^{1}$, Ekawee Sripariwuth ${ }^{1}$, Peerayut Sitthichaiyakul ${ }^{2}$ \\ Departments of ${ }^{1}$ Internal Medicine and ${ }^{2}$ Pathology, Faculty of Medicine, Naresuan University Hospital, Phitsanulok, Thailand
}

Colonic mucosal injury is rare, but may severely fatal, complications following the administration of calcium polystyrene sulfonate resins. The incidence rate is about $0.57 \%$, administered without sorbitol, and increases to $1.8 \%$ when it is concomitant with sorbitol, especially in postoperative patients. In this case report, we demonstrated the case of a 77-year-old female with stage $3 \mathrm{~b}$ chronic kidney disease presented with in-hospital hematochezia after 3 weeks of calcium polystyrene sulfonate administration. The colonoscopic findings showed several serpiginous ulcers with some oozing at descending and sigmoid colon. The histological findings revealed some focal inflammation and ulcerations with crystal-like materials, compatible with cation exchange resins. The recent in vitro study, explaining the pathogenesis of cation exchange resin-associated colonic mucosal injury, was also reviewed.

Keywords: Calcium polystyrene sulfonate; Colonic injury; Colonic necrosis; Gastrointestinal hemorrhage; Kalimate

\section{INTRODUCTION}

Hyperkalemia, defined as an abnormally high serum potassium level of more than $5.5 \mathrm{mEq} / \mathrm{L}$, is one of the most common electrolyte disorders. The annual prevalence of hyperkalemia in the overall population of the United States is $1.57 \%$, with higher rates observed in chronic kidney disease (CKD), heart failure, and diabetic patients. Among patients with $\mathrm{CKD}$ and/or heart failure, the prevalence is $6.35 \%$ [1]. Hyperkalemia can result in many consequences, including myopathy, peripheral neuropathy, and even fatal cardiac arrhythmia. In a meta-analysis, the adjusted hazard ratio for all-cause mortality in CKD with hyperkalemia is 1.22 [2]. Cation exchange resins (CERs), such as sodium polystyrene sulfonate (SPS) and calcium polystyrene sulfonate (CPS), have been

Received: Feb 11, 2021 - Revised: Mar 17, 2021 - Accepted: Mar 19, 2021 Correspondence to: Setthachai Piwchan, M.D

Department of Internal Medicine, Faculty of Medicine, Naresuan University Hospital, 99 Tha Pho, Mueang, Phitsanulok 65000, Thailand

Tel: +66-898603135, Fax: +66-55965105

E-mail: setthachaipw@gmail.com

ORCID: https://orcid.org/0000-0003-2101-9002

(C) 2022 The Korean Society of Coloproctology

This is an open-access article distributed under the terms of the Creative Commons Attribution NonCommercial License (https://creativecommons.org/licenses/by-nc/4.0) which permits unrestricted noncommercial use, distribution, and reproduction in any medium, provided the original work is properly cited. used for treating this condition since 1958. Unlike SPS, CPS binds to potassium ions in the gastrointestinal tract, especially colon, and exchanges for calcium ions which is safely used in sodiumrestricted patients.

CERs have been associated with various gastrointestinal side effects such as nausea/vomiting, bowel obstruction, and diarrhea. SPS dissolved in water could result in bezoars formation leading to bowel obstruction. This drug was later administered in sorbitol, which had been associated with severe osmotic injury resulting in colonic necrosis. This association was first reported by Arvanitakis et al. [3] in 1973. In 1987, Lillemoe et al. [4] presented 5 kidney transplant cases suffering from colonic necrosis after receiving an enema of SPS in a 70\% sorbitol solution. CERs can also injure the stomach and small bowel mucosae $[5,6]$.

Since the 2000s, CPS-induced colonic necrosis was more recognized. There were about 6 case reports and 1 retrospective analysis [6-12]. Herein, we presented a case report of a 77-year-old female with CPS associated in-hospital lower gastrointestinal bleeding and also reviewed the relevant literature, including the recent purposed pathogenesis of this complication.

\section{CASE REPORT}

A 77-year-old woman with type 2 diabetes mellitus and stage $3 \mathrm{~b}$ CKD was admitted to the hospital because of exertional dyspnea 
with hypoxia. She had been admitted to another hospital with infective diarrhea complicated with acute kidney injury and hyperkalemia 3 weeks before. Four doses of $30 \mathrm{~g}$ of CPS without dextrose were given orally. She was discharged after receiving adequate hydration and proper antibiotic treatment. On physical examination, she was afebrile with tachypnea. A contrast-enhanced chest computed tomography demonstrated several filling defects of the interlobar pulmonary artery of the right middle lung and lower lung. There was also ground-glass opacity in the right middle lung. She was diagnosed with acute pulmonary thromboembolism and lung infarction. Enoxaparin was given subcutaneously.

On the second day, she developed hematochezia. Her hemoglo-

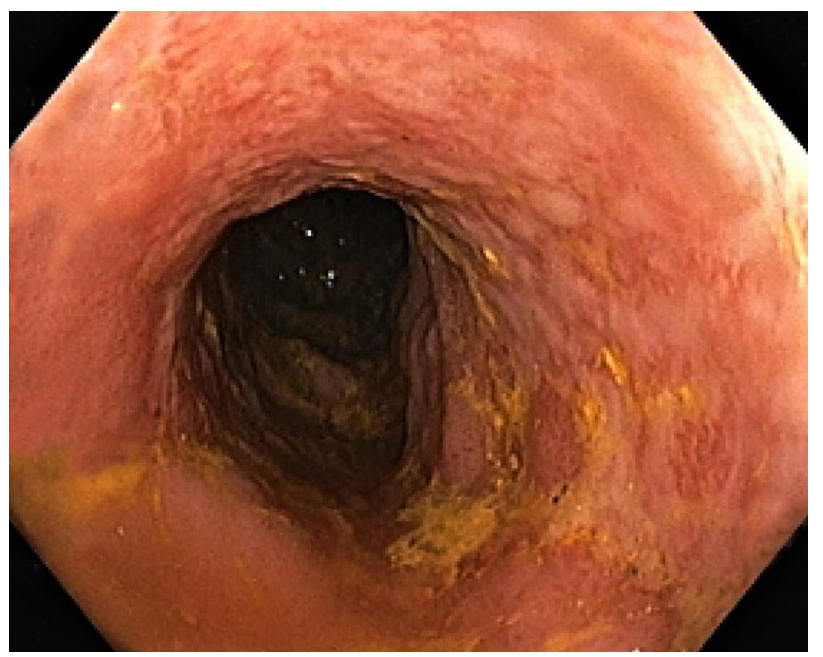

Fig. 1. Several serpiginous ulcers with nodularity and irregularity of mucosa at descending and sigmoid colon.

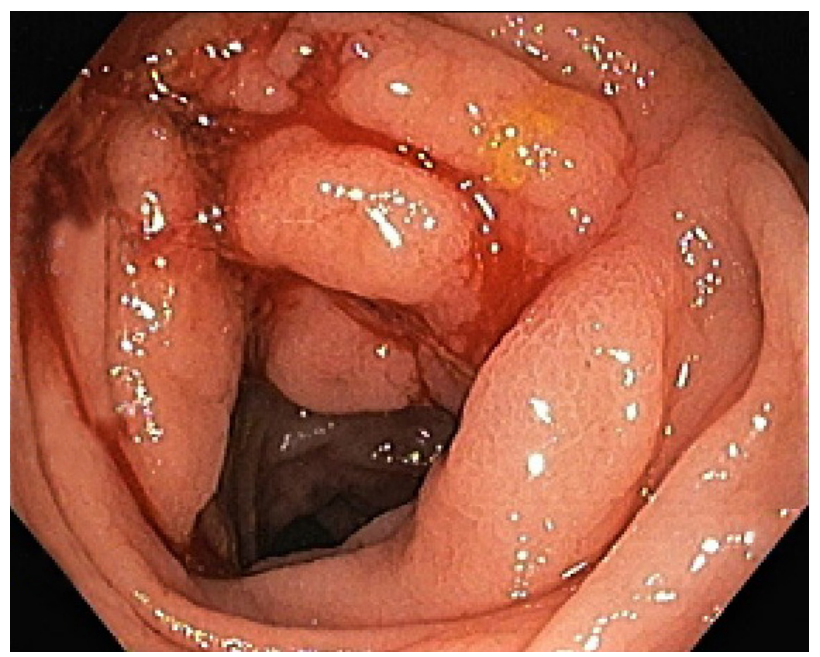

Fig. 2. The oozing spots at some ulcers at the descending colon. bin level had decreased from 8.9 to $6.3 \mathrm{~g} / \mathrm{dL}$. The physical examination was unremarkable except for pale conjunctivae. The colonoscopic findings showed several serpiginous ulcers with nodularity and irregularity of mucosa at descending and sigmoid colon (Fig. 1). There were oozing spots at some ulcers at the descending colon (Fig. 2). The differential diagnoses were ischemic colitis, cytomegalovirus (CMV) colitis, inflammatory bowel disease, and lymphoma. Random biopsies for histologic diagnosis were performed.

The pathologic report revealed focal ulcerations with granulation tissue and crystal-like materials, dense infiltrations of lymphocytes, plasma cells, and neutrophils in the lamina propria. There was neither cryptitis nor crypt distortion. No granuloma,

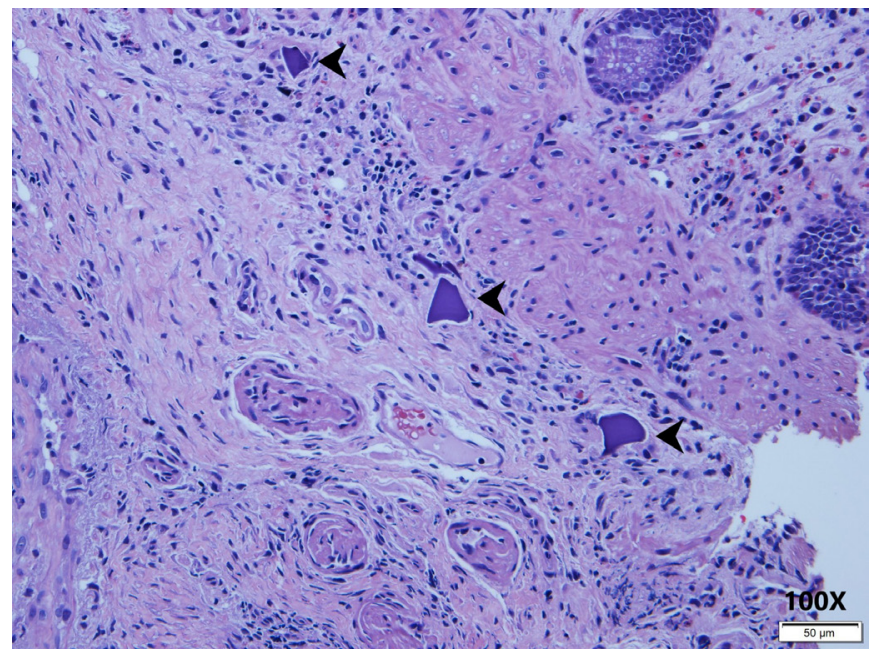

Fig. 3. The H\&E staining $(\times 100)$ revealed focal ulcerations with granulation tissue and violet crystal-like materials (arrowheads).

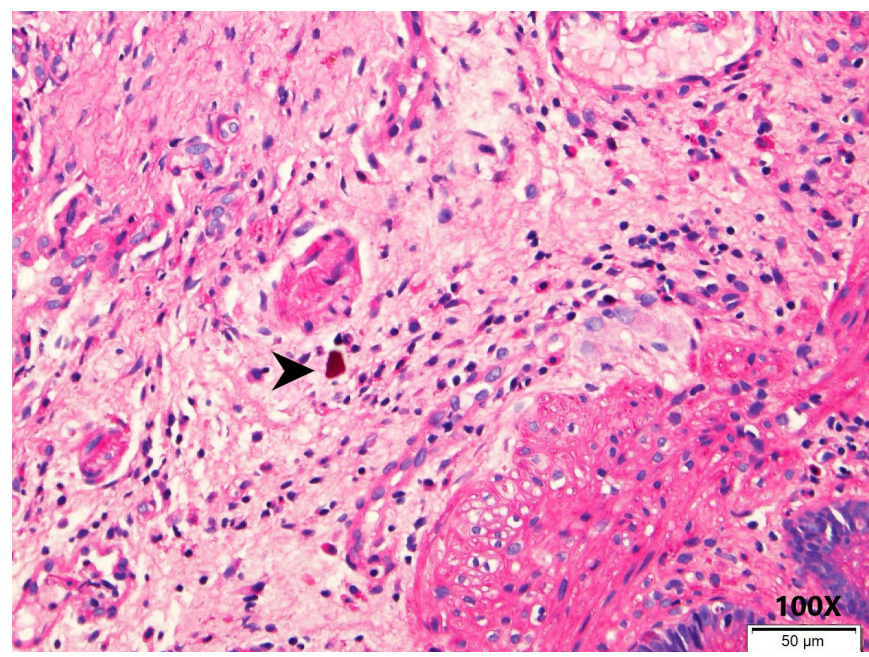

Fig. 4. The periodic acid-Schiff staining $(\times 100)$ showed a dark-red resin crystal (arrowhead). 
malignancy, or viral cytopathic effect was observed. The acid-fast bacillus and CMV staining were negative. The crystal-like materials were violet on hematoxylin and eosin (H\&E) staining (Fig. 3) and dark red on periodic acid-Schiff (PAS) staining (Fig. 4). These materials were compatible with CER crystals. The CPS-associated colonic mucosal injury was diagnosed. She was uneventfully discharged after conservative treatment. This report was approved from the Institutinal Review Board of Naresuan University (No. P3-0081/2564). Written informed consent was obtained for publication of this case report and accompanying images.

\section{DISCUSSION}

Hyperkalemia is one of the most common electrolyte disorders. The management of hyperkalemia can be achieved through the implementation of various interventions, such as rapid redistribution of potassium into the cell and removal of potassium through the kidneys, the gastrointestinal tract, or by performing dialysis. Nonabsorbable CERs are able to interfere with potassium absorption at the colon and exchange with sodium or calcium. Unfortunately, these types of medications are associated with many adverse events which are diarrhea, bowel obstruction, and gastrointestinal mucosal damage.

Arvanitakis et al. [3] first reported 3 cases of ischemic colitis, aggravated by SPS crystals, in 1973. The experimental study of Lillemoe et al. [4] in 1987 was the most impressive. In rats, sorbitol alone and SPS in sorbitol enemas promoted colonic necrosis. At that time, it was believed that sorbitol alone could cause osmotic injury to the colonic mucosa due to the dysfunction of ATP-de- pendent $\mathrm{Na}^{+}-\mathrm{K}^{+}$pumps. The prevalence of the necrosis occurred in approximately $1 \%$ of patients treated with SPS and sorbitol and may be up to $1.8 \%$ in postoperative patients [13]. In September 2009, the high frequency of severe adverse event reports led the United States Food and Drug Administration to remove recommendations for concomitant administration of these resins in sorbitol.

CPS is available worldwide, except in the United States. Since the 2000s, CPS-induced colonic necrosis was more recognized. There were about 6 case reports [6-11]. Clinicopathological findings of CPS-associated colonic injury are summarized in Table 1. CPS, with or without sorbitol, associated injury commonly occurred in the sigmoid colon and cecum. It could present in either an acute (as early as 2 days after exposure) or chronic setting. The dosages of calcium polystyrene sulfonate were varied from 15 to $155 \mathrm{~g}$ in both oral administration and rectal enema. The pathologic findings could be as mild as diffuse colitis or as severe as colonic perforation. The majority of the cases had 1 or more cardiovascular risks, such as coronary heart disease, type 2 diabetes mellitus, and $\mathrm{CKD}$, which could be precipitating factors for gastrointestinal mucosal damage. In our patient, the descending and sigmoid ulcerations occurred 3 weeks after 4 doses of $30 \mathrm{~g}$ of CPS given orally. Similar to aforementioned report, a recent retrospective analysis of 61 end-stage renal disease (ESRD) patients with intestinal perforation showed the incidence of CER, without sorbitol, related intestinal necrosis was estimated at $0.57 \%$. The common perforation site was in the sigmoid colon (82.6\%). The average dosage and administration period of CER were $17.4 \pm 8.3 \mathrm{~g} /$ day (5-30 g/day) and 40.5 \pm 50.3 months (0.5-188 months), re-

Table 1. Summary of clinical details and histological features

\begin{tabular}{|c|c|c|c|c|c|c|c|c|c|c|}
\hline Study & Year & Age (yr) & Sex & Clinical detail & Dosage of CPS & $\begin{array}{c}\text { Time } \\
\text { interval }\end{array}$ & $\begin{array}{l}\text { Endoscopic } \\
\text { finding }\end{array}$ & Site & $\begin{array}{l}\text { Histopathologic } \\
\text { finding }\end{array}$ & $\begin{array}{l}\text { Associated } \\
\text { condition }\end{array}$ \\
\hline $\begin{array}{l}\text { Shioya et al. } \\
\text { [7] }\end{array}$ & 2007 & 77 & Female & $\begin{array}{l}\text { Abdominal } \\
\text { pain/vomiting }\end{array}$ & $\begin{array}{l}15 \mathrm{~g} \text { with sorbitol } \\
\text { orally }\end{array}$ & 9 days & $\begin{array}{l}\text { Dirty-white } \\
\text { coated erosion }\end{array}$ & Sigmoid colon & $\begin{array}{l}\text { Diffuse and exten- } \\
\text { sive inflammation }\end{array}$ & T2DM, CAD \\
\hline Joo et al. [8] & 2009 & 34 & Male & $\begin{array}{l}\text { Profuse } \\
\text { hematochezia }\end{array}$ & $\begin{array}{l}155 \mathrm{~g} \text { without } \\
\text { sorbitol orally/60 g } \\
\text { with } 20 \% \mathrm{DW} \\
\text { enema }\end{array}$ & 2 days & $\begin{array}{l}\text { Active ulceration } \\
\text { with mucosal } \\
\text { necrosis and } \\
\text { hemorrhage }\end{array}$ & $\begin{array}{l}\text { Sigmoid colon/ } \\
\text { rectum }\end{array}$ & $\begin{array}{l}\text { Necroinflammation } \\
\text { or ulceration }\end{array}$ & ESRD, HTN \\
\hline $\begin{array}{l}\text { Goutorbe } \\
\text { et al. [9] }\end{array}$ & 2011 & 74 & Female & $\begin{array}{l}\text { Jejunal } \\
\text { perforation } \\
\text { (death) }\end{array}$ & $\begin{array}{l}60 \mathrm{~g} \text { without sorbitol } \\
\text { orally }\end{array}$ & 6 days & NA & Jejunum/cecum & $\begin{array}{l}\text { Transmural abscess } \\
\text { with inflammation } \\
\text { and ulceration }\end{array}$ & COPD \\
\hline $\begin{array}{l}\text { Akagun et al. } \\
{[10]}\end{array}$ & 2011 & 78 & Female & $\begin{array}{l}\text { Sigmoid } \\
\text { perforation }\end{array}$ & $\begin{array}{l}\text { Orally without sorbitol } \\
\text { (chronic use) }\end{array}$ & NA & NA & Sigmoid colon & $\begin{array}{l}\text { Deep ulcer with } \\
\text { necroinflammation }\end{array}$ & CKD, HTN \\
\hline $\begin{array}{l}\text { Castillo-Cejas } \\
\text { et al. [11] }\end{array}$ & 2013 & 73 & Male & Hematochezia & $\begin{array}{l}\text { Orally without sorbitol } \\
\text { (chronic use) }\end{array}$ & NA & Ischemic lesions & $\begin{array}{l}\text { Cecum/ascend- } \\
\text { ing colon }\end{array}$ & Mucosal necrosis & ESRD, CAD \\
\hline Kao et al. [6] & 2015 & 59 & Female & $\begin{array}{l}\text { Sigmoid } \\
\text { perforation }\end{array}$ & $\begin{array}{l}60 \mathrm{~g} \text { without sorbitol } \\
\text { orally }\end{array}$ & 2 days & NA & Sigmoid colon & $\begin{array}{r}\text { Mucosal necrosis } \\
\text { with perforation }\end{array}$ & $\begin{array}{l}\text { T2DM, ESRD, } \\
\text { CAD }\end{array}$ \\
\hline Current case & 2020 & 77 & Female & Hematochezia & $\begin{array}{l}120 \mathrm{~g} \text { without } \\
\text { sorbitol orally }\end{array}$ & $3 w k$ & $\begin{array}{l}\text { Ulcerations with } \\
\text { hemorrhage }\end{array}$ & $\begin{array}{l}\text { Descending/ } \\
\text { sigmoid colon }\end{array}$ & $\begin{array}{l}\text { Ulceration and } \\
\text { inflammation }\end{array}$ & $\begin{array}{l}\text { T2DM, CKD, } \\
\text { HTN }\end{array}$ \\
\hline
\end{tabular}

CPS, calcium polystyrene sulfonate; T2DM, type 2 diabetes mellitus; CAD, coronary artery disease; DW, distilled water; ESRD, end-stage renal disease; HTN, hypertension; $\mathrm{NA}$, not available; COPD, chronic obstructive pulmonary disease; CKD, chronic kidney disease. 
spectively [13]. The latest in vitro study explained the pathogenesis of CERs associated mucosal necrosis by diminishing the metabolic activity, forming a neutrophil and monocyte extracellular trap leading to cell death, and causing barrier dysfunction of intestinal epithelial cells. The crystals may further contribute to the auto-amplification of a preexisting barrier dysfunction and necroinflammation [14].

Gastrointestinal complications in the patients who had multiple problems, especially CKD/ESRD, were not uncommon. Ischemic colitis and opportunistic infections are the main differential diagnoses other than CER-associated colitis. Endoscopic findings might not be sufficient to differentiate these conditions; pathologic findings played a critical role in the diagnosis. The observation of angulated crystals with a characteristic crystalline mosaic pattern is essential to diagnosis. CERs, both SPS and CPS, were basophilic or violet on H\&E staining and deep red on PAS staining.

The CERs are rarely associated with colonic mucosal injury. Clinicians should be concerned about this condition in their patients, especially in CKD, with a history of administration of these drugs. The variety in dosage and duration could contribute to various clinical complications. However, 1 retrospective observational study demonstrated a low dose of $15 \mathrm{~g}$ of SPS (about 2-week duration) was well-tolerated and could effectively normalize the elevated serum potassium [15].

\section{CONFLICT OF INTEREST}

No potential conflict of interest relevant to this article was reported.

\section{FUNDING}

None.

\section{ORCID}

Setthachai Piwchan, https://orcid.org/0000-0003-2101-9002

Ekawee Sripariwuth, https://orcid.org/0000-0003-2924-1337

Peerayut Sitthichaiyakul, https://orcid.org/0000-0002-0685-4846

\section{ACKNOWLEDGMENTS}

The authors are grateful to Dr. Marry Elizabeth Sarawit of the Naresuan University Language Centre for her assistance on English expression in this document.

\section{REFERENCES}

1. Betts KA, Woolley JM, Mu F, McDonald E, Tang W, Wu EQ. The prevalence of hyperkalemia in the United States. Curr Med Res Opin 2018;34:971-8.

2. Kovesdy CP, Matsushita K, Sang Y, Brunskill NJ, Carrero JJ, Chod- ick G, et al. Serum potassium and adverse outcomes across the range of kidney function: a CKD Prognosis Consortium metaanalysis. Eur Heart J 2018;39:1535-42.

3. Arvanitakis C, Malek G, Uehling D, Morrissey JF. Colonic complications after renal transplantation. Gastroenterology 1973;64: 533-8.

4. Lillemoe KD, Romolo JL, Hamilton SR, Pennington LR, Burdick JF, Williams GM. Intestinal necrosis due to sodium polystyrene (Kayexalate) in sorbitol enemas: clinical and experimental support for the hypothesis. Surgery 1987;101:267-72.

5. Abraham SC, Bhagavan BS, Lee LA, Rashid A, Wu TT. Upper gastrointestinal tract injury in patients receiving kayexalate (sodium polystyrene sulfonate) in sorbitol: clinical, endoscopic, and histopathologic findings. Am J Surg Pathol 2001;25:637-44.

6. Kao CC, Tsai YC, Chiang WC, Mao TL, Kao TW. Ileum and colon perforation following peritoneal dialysis-related peritonitis and high-dose calcium polystyrene sulfonate. J Formos Med Assoc 2015;114:1008-10.

7. Shioya T, Yoshino M, Ogata M, Shibuya T, Tokunaga A, Matsumoto K, et al. Successful treatment of a colonic ulcer penetrating the urinary bladder caused by the administration of calcium polystyrene sulfonate and sorbitol. J Nippon Med Sch 2007;74:359-63.

8. Joo M, Bae WK, Kim NH, Han SR. Colonic mucosal necrosis following administration of calcium polystryrene sulfonate (Kalimate) in a uremic patient. J Korean Med Sci 2009;24:1207-11.

9. Goutorbe P, Montcriol A, Lacroix G, Bordes J, Meaudre E, Souraud JB. Intestinal necrosis associated with orally administered calcium polystyrene sulfonate without sorbitol. Ann Pharmacother 2011;45:e13.

10. Akagun T, Yazici H, Gulluoglu MG, Yegen G, Turkmen A. Colonic necrosis and perforation due to calcium polystyrene sulfonate in a uraemic patient: a case report. NDT Plus 2011;4:402-3.

11. Castillo-Cejas MD, de-Torres-Ramírez I, Alonso-Cotoner C. Colonic necrosis due to calcium polystyrene sulfonate (Kalimate) not suspended in sorbitol. Rev Esp Enferm Dig 2013;105:232-4.

12. Murakami K, Nakamura Y, Miyasaka Y, Sato T, Kawagishi N, Sasano $\mathrm{H}$. Intestinal necrosis related to administration of cation exchange resin without sorbitol: a retrospective analysis of $61 \mathrm{pa}-$ tients with end-stage renal diseases. Pathol Int 2020;70:270-9.

13. Gerstman BB, Kirkman R, Platt R. Intestinal necrosis associated with postoperative orally administered sodium polystyrene sulfonate in sorbitol. Am J Kidney Dis 1992;20:159-61.

14. Kim T, de Oliveira Silva Lautenschlager S, Ma Q, Eller K, Pollheimer MJ, et al. Drug crystal-related gastrointestinal complications involve crystal-induced release of neutrophil and monocyte extracellular traps. Cells 2020;9:2481.

15. Georgianos PI, Liampas I, Kyriakou A, Vaios V, Raptis V, Savvidis $\mathrm{N}$, et al. Evaluation of the tolerability and efficacy of sodium polystyrene sulfonate for long-term management of hyperkalemia in patients with chronic kidney disease. Int Urol Nephrol 2017;49: 2217-21. 